\title{
PENGARUH AUTOGENIC TRAINING TERHADAP STRES PADA ORANG DENGAN HIV/AIDS
}

\author{
Eva Dwi Ramayanti ${ }^{1}$, Arif Nurma Etika ${ }^{2}$ \\ Fakultas Ilmu Kesehatan Universitas Kadiri \\ Email: eva.dwi@unik-kediri.ac.id
}

\begin{abstract}
ABSTRAK
Stres merupakan faktor ekstrenal maupun internal yang membuat adaptasi menjadi sulit dan menyebabkan meningkatnya usaha seseorang untuk mempertahankan keseimbangan antara dirinya dan lingkungan. Stres pada orang dengan HIV/AIDS disebabkan karena kondisi fisik yang memburuk, ancaman kematian, serta adanya tekanan sosial yang begitu hebat. Survey awal menunjukkan prevalensi stres pada orang dengan HIV/AIDS tergolong tinggi, hal ini akan semakin memperburuk kondisinya. Penatalaksanaan pada stres tidak hanya dengan metode farmakologis saja, tetapi juga dapat dilakukan dengan pengobatan non-farmakologis. Salah satu teknik non farmakologis yang diduga bisa membantu dalam menurunkan stres pada orang dengan HIV/AIDS adalah Autogenic training. Autogenic training merupakan suatu metode manajemen stres dengan menggunakan pendekatan yang holistik. Tujuan penelitian ini adalah untuk mengetahui pengaruh autogenic training terhadap stres pada orang dengan HIV/AIDS di Kota Kediri tahun 2019. Desain yang digunakan dalam penelitian ini adalah one group pre eksperimen designs dengan menggunakan rancangan pre-post test design. Populasi dalam penelitian ini sebanyak 21 orang dan jumlah sampelnya adalah 20 orang yang dipilih dengan teknik purposive sampling. Pada responden dilakukan autogenic training sebanyak tiga kali dan diukur tingkat stres sebanyak dua kali. Uji statistik yang digunakan adalah uji wilcoxon. Hasil penelitian menunjukkan sebelum dilakukan terapi sebagian besar responden mengalami stres sedang, sedangkan sesudah terapi sebagian besar responden mengalami stres normal. Hasil uji statistik menunjukkan ada pengaruh pemberian Autogenic Training terhadap stres pada Orang dengan HIV/AIDS di Kota Kediri Tahun 2019 dengan p-value sebesar 0,00. Berdasarkan hasil ini diharapkan autogenic training dapat digunakan sebagai intervensi dalam program manajemen stres untuk Orang dengan HIV/AIDS.
\end{abstract}

Kata Kunci : Autogenic Training, Stres, HIV/AIDS 
PENDAHULUAN

Acquired Immuno Deficiency Syndrome (AIDS) adalah penyakit yang menyerang sistem kekebalan tubuh sehingga mengakibatkan melemahnya sistem kekebalan tubuh, AIDS disebabkan oleh infeksi Human Immunodeficiency Virus (HIV). Permasalahan yang terkait dengan HIV/AIDS adalah masalah yang serius di seluruh dunia, karena jumlah penderitanya sendiri akan terus mengalami kenaikan (Yudiati \& Rahayu, 2017). Penyakit HIV/AIDS menimbulkan masalah yang cukup luas pada individu yang terinfeksi yakni meliputi masalah fisik, sosial, dan emosional. Dengan kondisi fisik yang memburuk, ancaman kematian, serta adanya tekanan sosial yang begitu hebat menyebabkan orang dengan HIV/AIDS cenderung mengalami masalah emosional atau psikososial (Kusuma, 2011). Masalah emosional yang sering dialami oleh orang dengan HIV/AIDS adalah stres. Hal ini didukung oleh penemuan Iskandar bahwa di Indonesia dari hasil penelitian kualitatif yang dilakukan pada 6 orang pasien HIV/AIDS di Jakarta didapatkan keseluruhan informan mengalami stres (Girianto, PWR., 2017). Dari survei awal yang dilakukan peneliti pada 10 responden ditemukan 2 orang (20\%) menderita stres berat, 6 orang $(60 \%)$ menderita stres sedang dan 2 lainnya (20\%) mengalami stres ringan. Hal ini menunjukkan bahwa orang dengan HIV/AIDS di Kota Kediri memiliki kejadian stres yang tinggi.
Humphrey, Yow \& Bowden mengungkapkan bahwa stres merupakan faktor yang bertindak baik secara eksternal maupun internal yang membuat adaptasi menjadi sulit dan menyebabkan meningkatnya usaha yang dilakukan seseorang untuk mempertahankan keseimbangan antara dirinya dan lingkungan luar (eksternal) (Fathia, Shanti, \& Azizah, 2017). Stres pada penderita HIV/AIDS akan semakin memperburuk kondisinya. Dampak psikososial pada pasien HIV/AIDS pada awalnya belum muncul gejala, stres masih ringan. Tetapi seiring berjalannya waktu dimana fungsi imun semakin menurun dan mulai ada tanda yang berhubungan dengan HIV seperti ruam kulit, penurunan berat badan, sesak nafas, dan sebagainya maka pasien akan semakin meningkat stresnya, semakin cemas dan depresi. Mungkin pula disertai dengan gagasan bunuh diri, gangguan tidur dan sebagainya (Alim, Muhammad., 2010). Oleh karena itu penanganan tidak hanya dari segi medis tetapi juga aspek psikososial agar orang dengan HIV/AIDS mampu beradaptasi akibat kesedihan dan stres yang dialami.

Upaya non farmakologi yang dapat diberikan untuk menanggulangi stres adalah dengan manajemen stres. Beberapa penelitian menunjukkan salah satu pendekatan non farmakologi yang dapat menurunkan stres adalah relaksasi. Relaksasi merupakan cara menejemen stres yang baik, dan autogenic training adalah salah satunya (Lim \& Kim, 
2014). Salah satu teknik relaksasi yang diduga bisa membantu dalam menurunkan stres pada orang dengan HIV/AIDS adalah Autogenic training. Autogenic training dikembangkan oleh Johannes Schultz di Jerman pada tahun 1920 dan 1930. Autogenic training merupakan suatu latihan yang bertujuan untuk memberikan efek relaksasi, meringankan gangguan psikosomatik, termasuk pada beberapa kasus insomnia, ketidakmampuan berkonsentrasi, tekanan darah tinggi. Autogenic training mengacu pada teknik tertentu latihan mental yang melibatkan relaksasi dan sugesti, yang bertujuan untuk mengajarkan individu untuk mematikan melawan/memerangi respons stres yang dialami (Kusmiran, Octovia Manalu, \& Umanah, 2014). Pada penelitian Fathia (2017) diperoleh hasil bahwa Autogenic training yang dilakukan selama 15 menit selama 3 hari, secara signifikan mampu menurunkan respons stres mahasiswa keperawatan.

\section{METODE}

Desain yang digunakan dalam penelitian ini adalah one group pre eksperimen designs dengan menggunakan rancangan pre-post test design. Populasi pada penelitian ini adalah orang dengan HIV/AIDS Kota Kediri di Kelompok Dukungan Sebaya (KDS) Friendship Plus Kediri pada Bulan September 2018 yang mengalami stres.

Teknik sampling yang digunakan dalam penelitian ini adalah metode purposive sampling. Sampel pada penelitian berjumlah
20 orang dengan kriteria inklusi: 1) Didiagnosa HIV positif sejak minimal 1 bulan yang lalu; 2) Berusia > 18 tahun (kelompok usia dewasa); 3) Dapat membaca dan menulis; 4) Kesadaran compos mentis; 5) Bersedia berpartisipasi dalam penelitian dan kooperatif. Kriteria eksklusi: 1) Mengalami ketidaknyamanan fisik yang memberat (seperti nyeri, pusing, atau lainnya) sehingga tidak memungkinkan untuk responden melanjutkan penelitian; 2) Memutuskan untuk tidak melanjutkan pengisian ataupun tidak mengisi secara lengkap kuesioner.

Instrumen yang digunakan dalam penelitian ini adalah kuisioner untuk mengukur stres yaitu DASS (Depression, Anxiety and Stress Scale) dengan 42 item pertanyaan yang sudah teruji validitas secara international. Hasil uji reliabilitas instrumen reliabel dan mempunyai nilai reliabilitas sebesar 0,91 yang diolah berdasarkan penilaian Cronbac's alpha.

Peneliti mengurus perizinan studi pendahuluan dari Fakultas Ilmu Kesehatan Universitas Kadiri. Selanjutnya peneliti menyerahkan surat izin survei ke KPAD Kota Kediri dan KDS Frienship Plus Kediri. Peneliti menyosialisasikan maksud dan tujuan penelitian kepada ketua KDS Frienship Plus Kediri dan melakukan pengumpulan data orang dengan HIV/AIDS yang menderita stres. Selanjutnya peneliti menentukan responden yang memenuhi kriteria inklusi sesuai dengan teknik pengambilan sampel. Sebelum memberikan terapi peneliti 
memberikan inform consent dan kuisioner untuk mengukur tingkat stres kepada responden. Dalam pelaksanaan terapi melaksanakan autogenic training selama 1015 menit selama 3 kali dalam 3 hari dengan total responden. Setelah pelaksanaan terapi peneliti memberikan kuisioner untuk mengukur tingkat stres post terapi kepada responden. Analisa data menggunakan uji Wilcoxon Signed Ranks Test.

\section{HASIL}

\section{a. Karakteristik Responden}

Responden pada penelitian ini terdiri dari 17 orang atau $75 \%$ berjenis kelamin perempuan dan 3 orang atau $25 \%$ berjenis kelamin lakilaki. Rentang usia responden yaitu sebanyak 1 orang atau 5\% berusia 20-24 tahun, 4 orang atau 20\% berusia 25-35 tahun, 11 orang atau $55 \%$ berusia 36-45 tahun dan 4 orang atau $20 \%$ berusia 46-55 tahun. Pendidikan responden dalam penelitian ini yaitu 1 orang atau 5\% tidak sekolah, 14 orang atau $70 \%$ berpendidikan SD/SMP, dan 5 orang atau $25 \%$ berpendidikan SMA. Pekerjaan responden yaitu 2 orang atau $10 \%$ tidak bekerja dan 18 orang atau $90 \%$ bekerja swasta. Status pernikahan dalam penelitian ini adalah 13 orang atau $65 \%$ berstatus menikah, 1 orang atau $5 \%$ belum menikah, dan 6 orang atau 30\% berstatus janda/duda. Sebanyak 16 responden atau $80 \%$ responden tinggal sendiri dan 4 orang atau $20 \%$ tinggal sendiri. Penghasilan seluruh responden atau $100 \%$ dalam penelitian ini kurang dari UMR Kediri yaitu $\operatorname{Rp} 1.700 .000$

\section{b. Stres Responden Sebelum Melakukan Autogenic Training}

Tabel 1. Distribusi Frekuensi Tingkat Stres Sebelum Terapi pada Orang dengan HIV/AIDS di Kota Kediri

\begin{tabular}{ccc}
\hline Kategori & \multicolumn{2}{c}{ Tingkat Stres } \\
& Sebelum Terapi \\
\cline { 2 - 3 } & $\mathrm{f}$ & $\%$ \\
\hline Stres Normal & 0 & 0 \\
Stres Ringan & 9 & 45 \\
Stres Sedang & 11 & 55 \\
Stres Berat & 0 & 0 \\
Stres Sangat Berat & 0 & 0 \\
\hline Total & 20 & 100 \\
\hline
\end{tabular}

\section{c. Stres Responden Sesudah Melakukan Autogenic Training}

Tabel 2. Distribusi Frekuensi Tingkat Stres Sesudah Terapi pada Orang dengan HIV/AIDS di Kota Kediri

\begin{tabular}{ccc}
\hline Kategori & \multicolumn{2}{c}{ Tingkat Stres } \\
& \multicolumn{2}{c}{ Sesudah Terapi } \\
\hline Stres Normal & F & $\%$ \\
Stres Ringan & 8 & 55 \\
Stres Sedang & 1 & 40 \\
Stres Berat & 0 & 5 \\
Stres Sangat Berat & 0 & 0 \\
\hline Total & 20 & 0 \\
\hline
\end{tabular}

\section{d. Pengaruh Autogenic Training terhadap Stres pada Orang dengan HIV/AIDS di Kota Kediri}

Tabel 3 Tingkat Stres Sebelum dan Sesudah Melakukan Autogenic Training pada Orang dengan HIV/AIDS di Kota Kediri 


\begin{tabular}{lccccc}
\hline Variabel & \multicolumn{2}{c}{ Sebelum } & \multicolumn{3}{c}{ Sesudah } \\
\cline { 2 - 6 } & Kategori & $\mathrm{F}$ & $\%$ & $\mathrm{~F}$ & $\%$ \\
\hline Tingkat & Stres Normal & 0 & 0 & 11 & 55 \\
Stres & & & & & \\
& Stres Ringan & 9 & 45 & 8 & 40 \\
& Stres Sedang & 11 & 55 & 1 & 5 \\
& Stres Berat & 0 & 0 & 0 & 0 \\
& Stres Sangat & 0 & 0 & 0 & 0 \\
& Berat & & & & \\
\hline$\sum$ & & 20 & 100 & 20 & 100 \\
\hline P value & & $\alpha:$ & & & \\
$: 0,00$ & & 0,05 & & & \\
\hline
\end{tabular}

HIV/AIDS yang dapat menimbulkan stres pada penderitanya.

Tingkat stres responden yang didapatkan dari penelitian ini sebagian besar tergolong stres sedang. Hal ini menunjukkan bahwa stres yang dialami oleh orang dengan HIV/AIDS pada penelitian ini tergolong masih tinggi walaupun mereka telah tergabung ke dalam kelompok dukungan.

\section{PEMBAHASAN}

\section{a. Tingkat Stres Sebelum Melakukan Autogenic Training pada Orang dengan HIV/AIDS di Kota Kediri}

Berdasarkan tabel 1 diperoleh hasil penelitian pada Orang dengan HIV/AIDS di Kota Kediri tahun 2019 sebelum dilakukan Autogenic Training didapatkan sebagian besar dari responden yaitu 11 responden (55\%) mengalami stres sedang dan sebanyak 9 responden (45\%) mengalami stres ringan. Hal ini sejalan dengan penemuan Hidayati (2013) yang menyatakan bahwa prevalensi stres pada orang dengan HIV/AIDS meningkat dua kali lipat dibandingkan populasi biasa.

Stres merupakan suatu keadaan dimana sumber yang dimiliki seseorang tidak cukup untuk merespons situasi yang sedang dialami. Dalam penelitian ini penyebabnya bisa dikarenakan faktor psikologis ataupun efek dari agen HIV yang sudah menginfeksi sistem saraf pusat. Perjalanan penyakit HIV/AIDS yang progresif, penyebaran yang luas dan cepat serta adanya stigma dan diskriminasi masyarakat pada pasien
Banyak hal yang menyebabkan hal ini, salah satunya adalah cara memandang suatu masalah sehingga masalah tersebut dapat dikatakan sebagai sumber stres atau tidak. Selain itu, masalah yang ditimbulkan oleh HIV/AIDS ini dapat terjadi pada berbagai hal. Ketidakmampuan orang dengan HIV/AIDS untuk menangani masalah tersebut juga menyebabkan stres yang tinggi.

\section{b. Tingkat Stres Sesudah Melakukan Autogenic Training pada Orang dengan HIV/AIDS di Kota Kediri}

Berdasarkan tabel 2 diperoleh hasil penelitian terhadap tingkat stres pada Orang dengan HIV/AIDS di Kota Kediri Tahun 2019 sesudah diberikan terapi didapatkan 11 orang atau sebagian besar (55\%) dari responden mengalami stres normal, stres ringan 8 responden (40\%) dan stres sedang sebanyak 1 responden (5\%). Dari 20 responden hampir seluruhnya mengalami perubahan tingkat stres dari yang tinggi ke tingkat stres yang lebih rendah. Hal ini dikarenakan kepatuhan penderita HIV/AIDS dengan stres mengikuti autogenic training dengan sungguh-sungguh. 
Hasil tersebut menunjukkan bahwa teknik autogenic training dapat menurunkan tingkat stres pada orang dengan HIV/AIDS. Davids, dkk dalam (Syafitri, 2018) menyatakan Autogenic Training dapat mengatur sistem saraf otonom terhadap stres yang dialami. Pada proses relaksasi terjadi pengurangan aktivitas otak sehingga denyut jantung menjadi normal, frekuensi nafas normal, tekanan darah menjadi normal, sehingga autogenic training dapat berespon dengan cepat dan efektif terhadap perintah verbal untuk rileks dan kembali pada keadaan seimbang dan normal.

Berdasarkan hasil penelitian dan teori menunjukkan setelah diberikan terapi sebagian besar responden berada dalam kategori stres normal. Hal tersebut dikarenakan efek dari autogenic training yang dapat membuat orang dengan HIV/AIDS menjadi rileks, nyaman, dan tenang. Stres normal yang dialami dapat diartikan bahwa orang dengan HIV/AIDS sudah mampu untuk mengatasi stres yang terjadi pada dirinya dan mampu menyesuaikan diri dengan lebih baik.

\section{c. Pengaruh Autogenic Training terhadap Stres pada Orang dengan HIV/AIDS di Kota Kediri}

Berdasarkan tabulasi silang didapatkan hasil sebelum diberikan Autogenic Training didapatkan sebagian besar (55\%) atau 11 responden mengalami stres sedang, dan 9 responden $(45 \%)$ mengalami stres ringan. Sedangkan sesudah diberikan Autogenic
Training sebagian besar responden yaitu 11 orang $(55 \%)$ mengalami stres normal, 8 responden (40\%) mengalami stres ringan, dan 1 responden (5\%) mengalami stres sedang. Hal ini dipengaruhi oleh ketekunan dan keseriusan responden dalam mengikuti Autogenic Training.

Berdasarkan perhitungan uji statistik menggunakan uji Wilcoxon didapatkan hasil $p$-value sebesar 0,00, karena p-value $<\alpha$ $(0,05)$ maka H0 ditolak dan H1 diterima yang artinya ada pengaruh pemberian Autogenic Training terhadap stres pada Orang dengan HIV/AIDS di Kota Kediri Tahun 2019. Penelitian ini sesuai dengan penelitian yang dilakukan oleh Fathia, 2017 yang menyebutkan bahwa Autogenic Training secara signifikan mampu menurunkan respons stres mahasiswa keperawatan. Hal ini diperkuat oleh (Syafitri, 2018) yang menyebutkan bahwa ada pengaruh Autogenic Training terhadap penurunan tingkat stres kerja di PT.AHM Yogyakarta.

Berdasarkan penelitian menunjukkan setelah diberikan Autogenic Training hampir seluruhnya responden mengalami penurunan tingkat stres. Hal ini dikarenakan efek dari Autogenic Training yang dapat membuat responden menjadi rileks, nyaman, tenang dan membuat responden kembali ke keadaan yang lebih baik. Pemberian Autogenic Training pada Orang dengan HIV/AIDS selama 15 menit yang dilakukan satu kali sehari selama tiga hari mampu menurunkan stres hal ini dikarenakan Autogenic Training memberikan 
efek menenangkan sehingga ketegangan yang dihadapi responden dapat menurun. Responden menjadi tenang dan pikiran menjadi lebih segar setelah diberikan Autogenic Training, hal tersebut menyebabkan stres menjadi berkurang. Pemberian Autogenic Training dapat menurunkan tingkat stres yang dialami oleh responden.

Dalam penelitian ini ditemukan 2 responden yang tidak mengalami penurunan tingkat stres, hal ini dikarenakan kurangnya konsentrasi dari responden. Dalam pemberian Autogenic Training harus dilaksanakan dengan konsentrasi yang pasif, rileks, lingkungan yang nyaman dan tenang agar efek dari relaksasi tersebut dapat membuat tubuh menjadi lebih rileks, bugar dan stres berkurang. Hal ini diperkuat dengan penelitian Syafitri (2018) yang menyatakan bahwa dalam pemberian teknik relaksasi autogenik pada karyawan harus dilaksanakan dengan konsentrasi yang pasif, rileks, lingkungan yang nyaman.

Autogenic Training jika dilakukan secara benar selama 15 menit akan mengaktifkan sistem ketenangan melalui korteks prefrontal. Secara biologis psikoterapi bekerja dalam rangkaian dan melibatkan berbagai struktur otak baik secara anatomis, seluler maupun tingkat biokimia, meliputi : fungsi persepsi, memori, kognitif, dan emosi. Dinamika antara amygdala dan reaksi dari pemberian informasi yang diterima korteks prefrontal mungkin menunjukkan model neuroanatomi bagaimana psikoterapi menata kembali pola emosi yang maladaptif. Hal ini juga memberi reaksi langsung pada sistem hormonal, sistem simpatis dan parasimpatis dan pada perilaku serta keterjagaan korteks. Stimulus tersebut kemudian akan disimpan di memori hipokampus yang nantinya secara sadar atau tidak, akan mempengaruhi stimulus berikut yang dipersepsikan. Dengan demikian, dengan latihan yang terus-menerus maka akan menyebabkan korteks prefrontal dapat memperbaiki respons terhadap stres (Fathia et al., 2017).

Sehingga dalam penelitian ini Autogenic Training dapat menurunkan tingkat stres yang sedang dialami oleh seseorang, terutama pada Orang dengan HIV/AIDS di Kota Kediri Tahun 2019. Hal tersebut menunjukkan bahwa autogenic training dapat digunakan sebagai intervensi dalam program manajemen stres untuk Orang dengan HIV/AIDS.

\section{KESIMPULAN}

Berdasarkan penelitian yang telah dilakukan maka dapat diambil kesimpulan bahwa:

1. Tingkat stres pada sebagian besar responden yaitu Orang dengan HIV/AIDS di Kota Kediri sebelum diberikan Autogenic Training mengalami stres sedang.

2. Tingkat stres pada sebagian besar responden yaitu Orang dengan HIV/AIDS di Kota Kediri sesudah diberikan Autogenic Training mengalami stres normal. 
3. Ada pengaruh pemberian Autogenic Training terhadap stres pada Orang dengan HIV/AIDS di Kota Kediri

\section{SARAN}

Hasil penelitian ini diharapkan dapat digunakan sebagai data dasar bagi penelitipeneliti selanjutnya.

\section{REFERENSI}

Fathia, N. A., Shanti, W., \& Azizah, K. (2017). Pengaruh Autogenic Training dalam Menurunkan Respons Stres Mahasiswa Keperawatan, 25-32. Girianto, PWR., W. (2017). Hubungan Dukungan Psikososial Keluarga dengan Tingkat Stres Pasien HIV/AIDS. Jurnal Kesehatan Mesencephalon, 3(1), 16-22.

Kusmiran, E., Octovia Manalu, L., \& Umanah, D. (2014). Relaksasi Nafas Dalam dan Relaksasi Autogenik terhadap Respons Skala Nyeri pada Ibu Post Seksio Sesarea. Jurnal INJEC, 1 .

Kusuma, H. (2011). Hubungan antara Depresi dan Dukungan Keluarga dengan Kualitas Hidup Pasien HIV/AIDS yang Menjalani Perawatan di RSUP Cipto Mangunkusumo Jakarta, 12. Retrieved from www.lib.ac.id

Lim, S. J., \& Kim, C. (2014). Effects of Autogenic Training on Stress Response and Heart Rate Variability in Nursing Students. Asian Nursing Research, 8(4), 286-292.

https://doi.org/10.1016/j.anr.2014.06.003

Syafitri, E. N. (2018). Pengaruh Teknik
Relaksasi Autogenik terhadap Penurunan Tingkat Stres Kerja pada Karyawan PT. Astra Honda Motor di Yogyakarta.

Jurnal Keperawatan Respati

Yogyakarta, 5(2), 395-398.

Yudiati, E. A., \& Rahayu, E. (2017). Coping

Stress dan Kecemasan pada Orang-

Orang Pengidap HIV/AIDS yang

Menjalani Tes Darah dan VCT

(Voluntary Counseling Testing), (April 2007), 270-279. 